\title{
PRINSIP KESANTUNAN BERBAHASA DALAM INTERAKSI ANTARA SISWA DENGAN GURU DI SMP NEGERI 2 KRIAN
}

\author{
Erlin Istiyanti, Luluk Isani Kulup \\ Pendidikan Bahasa dan Sastra Indonesia, Fakultas Keguruan dan Ilmu Pendidikan, \\ Universitas PGRI Adi Buana Surabaya \\ erlinistiyanti795@gmail.com, kulupluluk@gmail.com
}

\begin{abstract}
Unity of language is a norm or ethics to communicate in society. Therefore, people will recognize it so that everyone who has social interactions will use language appropriately and politely. Unity of language alone is not enough, if it is considered to make people speak politely. The solution is to pay attention to the principles of language unity. Everyone must know and understand about this, including elementary, middle, and high school students. The researcher used a qualitative approach because this study wanted to explain and describe the use of language unity as seen from the interaction between students and teachers at SMP Negeri 2 Krian. The data of this research is conversation or student speaking between teachers and students in SMP 2 Krian. The data sources for this study were teachers and students at SMP Negeri 2 Krian. Based on data analysis, the researcher found several maxims in the interaction of students and teachers at SMP Negeri 2 Krian. The principle of unity is based on Lech which is explained as the unity of language maxims. The maxims include (1) Wisdom; (2) Generosity; (3) Approval; (4) Courtesy; (5) Agreement; and (6) Sympathy. Therefore, it can be concluded that the interaction between students and teachers at SMP Negeri 2 Krian is polite. If it occurs because the interaction between students and teachers has fulfilled the politeness principle as stated by the maxim translated by Leech.
\end{abstract}

Keywords: Unity of language, and principle of language unity

\section{PENDAHULUAN}

Setiap manusia tentu akan bersosialisasi dengan manusia lain. Cara manusia untuk besosialisasi yaitu dengan cara berinteraksi sosial. Tentu saja berinteraksi dengan bertutur kata menggunakan bahasa. Bahasa adalah alat untuk berkomunikasi antar manusia. Bahasa tentu sangat penting dalam kehidupan manusia. Keraf (2004:01) berpendapat bahwa bahasa adalah alat komunikasi antara anggota masyarakat berupa simbol bunyi yang dihasilkan oleh alat ucap manusia.

Bahasa digunakan manusia untuk berkomunikasi dan berinteraksi sosial dengan berbicara yang baik dan benar. Setiap manusia ketika berinteraksi tentu harus berbicara dengan sopan dan santun. Karena dengan begitu orang yang menjadi lawan bicara akan merasa nyaman dan tidak terjadi hal yang tidak diinginkan.

Menurut Tarigan (2008:3), berbicara adalah suatu keterampilan berbahasa yang berkembang pada kehidupan anak, yang didahului oleh keterampilan menyimak, dan pada masa tersebutlah kemampuan berbicara atau berujar dipelajari. Oleh sebab itu dalam berbicara haruslah dengan santun sehingga akan tercipta komunikasi yang baik. Apabila dari anak-anak saja sudah tidak berbicara 
yang santun maka akan selamanya tidak memahami atau akan berbicara dengan tidak santun. Setiap individu tentu saja harus dapat berkomunikasi dengan baik agar tidak terjadi kesalah pahaman dengan lawan tutur.

Untuk dapat berkomunikasi dengan baik tentu antara penutur dan petutur harus mengetahui dengan siapa bertutur kata dan dalam konteks formal atau non formal. Juga harus mengetahui kesantunan berbahasa agar dalam berkomunikasi tidak terjadi kesalah pahaman.

Kesantunan berbahasa adalah norma atau etika dalam berkomunikasi di lingkungan masyarakat. Kesantunan berbahasa saja dinilai kurang cukup apabila untuk menjadikan masyarakat yang santun dalam berbahasa. Solusinya yaitu dengan memerhatikan prinsip-prinsip kesantunan berbahasa. Dengan demikian maka tujuan agar bahasa yang digunakan itu santun akan tercapai.

Prinsip kesantunan yaitu suatu sebuah aturan dalam berkomunikasi. Menurut Leech (dalam bukunya Chaer, 2010: 56), prinsip kesantunan terdapat enam maksim yakni maksim kebijaksanaan, maksim penerimaan, maksim kemurahan, maksim kerendahan hati, maksim kecocokan, dan maksim kesimpatian. Prinsip kesantunan berbahasa sangatlah penting dalam kegiatan berinteraksi sosial. Semua lapisan masyarakat haruslah mengetahui dan paham akan hal ini, tidak terkecuali siswa sekolah yang meliputi sekolah dasar, menengah pertama, dan menengah atas.

Mengapa para siswa perlu mengetahui prinsip-prinsip kesantunan berbahasa. Karena dengan mereka mengetahui prinsip kesantunan berbahasa yang ada maka para siswa yang merupakan generasi penerus bangsa ini akan berbahasa dengan santun kemudian tentu juga akan berperilaku santun pula.

Begitu juga siswa di SMP Negeri 2 Krian yang sebagian mampu berkomunikasi dengan santun dan sebagian tidak. Hal ini perlu dibenahi agar seluruh siswa di SMP Negeri 2 Krian mampu berkomunikasi dengan santun tidak hanya dengan Bapak atau Ibu guru melainkan dengan teman sebayanya. Dengan demikian akan mengurangi resiko kesalahpahaman dalam berkomunikasi.

Oleh karena itu, peneliti sangat tertarik dengan prinsip kesantunan berbahasa dalam interaksi siswa dengan guru di lingkungan SMP Negeri 2 Krian. Alasan kenapa meneliti hal tersebut yaitu dikarenakan prinsip kesantunan berbahasa sangatlah penting untuk diterapkan di kehidupan sehari-hari. Karena dengan demikian maka akan terbiasa untuk bertutur kata dengan bahasa yang santun. Berbahasa yang santun dapat diketahui dengan panjangnya kalimat. Semakin panjang kalimat yang diutarakan maka semakin santun pula bahasa yang digunakan.

Dengan permasalahan yang ada yakni bagaimana wujud penerapan prinsip kesantunan berbahasa ini di lingkungan SMP Negeri 2 Krian. Dari hal tersebut penulis berencana akan melakukan penelitian dengan judul "Prinsip Kesantunan Berbahasa dalam Interaksi Percakapan Antara Siswa dengan Guru di SMP Negeri 2 Krian".

\section{METODE}

Penelitian ini menggunakan pendekatan kualitatif. Data dalam penelitian adalah ujaran atau satuan-satuan percakapan antara siswa dengan guru. Sumber data dalam penelitian ini yakni percakapan interaksi antara siswa dan guru SMP Negeri 2 Krian. 
Teknik pengumpulan data pada penelitian ini menggunakan metode simak. Menurut Sudaryanto (1988:2-5) metode simak tersebut dilakukan dengan teknik sebagai berikut (1) teknik sadap; (2) teknik SLC; (3) teknik SBLC; (4) teknik rekam; dan (5) teknik catat.

Teknik analisis data yang digunakan dalam penelitian ini yaitu teknik deskriptif. Langkah untuk analisis data dalam penelitian ini yaitu sebagai berikut (1) Pentranskripsian data, (2) pengklasifikasian data, (3) pengkodean, (4) pengolahan data, dan (5) penarikan simpulan.

\section{TEMUAN DATA}

Berdasarkan temuan data dan analisis data ditemukan beberapa maksim kesantunan berbahasa dalam interaksi antara siswa dengan guru di SMP Negeri 2 Krian. Prinsip kesantunan berbahasa berdasarkan pendapat Leech yang dijabarkan menjadi maksim (ketentuan) kesantunan berbahasa. Maksim tersebut adalah maksim (1) kebijaksanaan; (2) penerimaan (3) kemurahan; (4) kerendahan hati; (5) kecocokan; dan (6) kesimpatian. Berdasarkan hasil analisis, maksim tersebut sebagi berikut.

Pertama, maksim kebijaksanaan yaitu mewajibkan setiap peserta pertuturan harus meminimalkan kerugian orang lain, atau memaksimalkan keuntungan bagi orang lain.

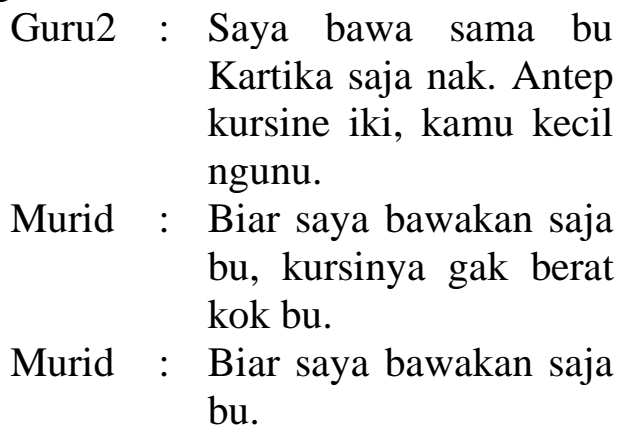

(D2/Mkeb/22Okt/01)

Kutipan di atas menunjukkan bahwa penutur dan lawan tutur menggunakan wujud maksim kebijaksanaan. Hal ini dapat diketahui dari tuturan murid yaitu "Biar saya bawakan saja bu, kursinya gak berat kok bu". Dari tuturan tersebut murid memaksimalkan keuntungan orang lain dengan rela membantu guru untuk membawakan kursi yang dibutuhkan oleh guru. Meskipun sebenarnya sang murid merasa tidak sanggup mengangkat kursi sendirian dengan postur tubuh murid yang kecil. Tetapi guru menolak pertolongan murid, karena guru berniat untuk mengangkatnya sendiri tanpa merepotkan orang lain. Guru juga bersikap santun karena guru memaksimalkan keuntungan orang lain dengan memaksimalkan kerugian pada dirinya. Tetapi pada penuturan murid selanjutnya, ia mencoba untuk memaksa guru agar diperbolehkan membantu guru mengangkat kursi. Hal menunjukkan bahwa murid menggunakan wujud maksim kebijaksanaan dengan memaksimalkan kerugian dirinya sendiri dan memaksimalkan keuntungan orang lain.

Kedua, maksim penerimaan yang menuntut peserta tuturan agar memaksimalkn kerugian diri sendiri dan memaksimalkan keuntungan orang lain. 
Terdapat tuturan yang mengandung maksim penerimaan dalam percakapan interaksi guru dengan siswa di SMPN 2 krian, sebagai berikut:

Murid : Haduh setipoku entek.

Murid : Ini loh Nisa pakek setipoku.

(D1/Mpen/20Okt/01)

Penggalan percakapan di atas merupakan penggalan pembicaraan antara murid dengan murid di dalam kelas. Murid yang pertama ketika menulis terjadi kesalahan penulisan dan akan dihapus menggunakan penghapus khusus bulpoin yang biasa disebut stipo atau tipe-x. Ternyata stipo murid tersebut habis. Kemudian murid yang kedua menawarkan bantuan kepada murid yang pertama "Ini loh Nisa pakek setipoku". Dari tuturan di atas terlihat bahwa murid yang kedua berusaha memaksimalkan keuntungan bagi orang lain dengan cara meminjamkan barang yang dibutuhkan oleh murid yang pertama. Karena kedekatan hubungan merekalah yang menyebabkan bereka saling membantu dan memberi satu sama lain.

Ketiga, maksim kemurahan adalah maksim yang menuntut setiap peserta pertuturan untuk memaksimalkan rasa hormat kepada orang lain atau meminimalkan rasa tidak hormat kepada orang lain. Menurut Nadar (2013:30) maksim diutarakan dengan tuturan ekspresif misalnya mengucapkan selamat dan memuji. Terdapat tuturan yang mengandung maksim kemurahan dalam percakapan interaksi guru dengan siswa di SMPN 2 krian, sebagai berikut:

Guru2 : Debora ini pinter anak-

anak. Makanya dia

menang ya.

Murid : Ndak bu, masih pintar

teman-teman.

Kebetulan saja saya

yang menang bu.

(D1/Mkem/20Okt/01)

Kutipan percakapan di atas menunjukkan bahwa ujaran antara penutur dan lawan tutur mematuhi maksim kemurahan. Hal ini dapat dibuktikan bahwa penutur guru berusaha untuk memaksimalkan keuntungan pada lawan tutur yaitu murid dengan memujinya. Guru (penutur) memuji dengan ujaran "Debora ini pinter anak-anak. Makanya dia menang ya", hal ini menunjukkan bahwa penutur mematuhi maksim kemurahan dengan memuji lawan tutur.

Keempat, Maksim kerendahan hati adalah maksim yang menuntut setiap peserta pertuturan untuk memaksimalkan ketidakhormatan pada diri sendiri, dan meminimalkan rasa hormat pada diri sendiri. Sedangkan menurut Nadar (2013:30) maksim ini berpusat pada diri sendiri , menuntut untuk memaksimalkan rasa tidak hormat pada diri sendiri. Terdapat tuturan yang mengandung maksim kerendahan hati dalam percakapan interaksi guru dengan siswa di SMPN 2 krian, sebagai berikut:

Murid : Rek, teksnya Arij loh apik ya?

Murid : Iya mbk, Arij memang 
T-O-P-B-G-T. Alias

pinter.

Murid : Walah, ndak kok. Lebih

bagus punya kalian.

(D4/Mker/27Okt/02)

Kutipan di atas menunjukkan bahwa penutur dan lawan tutur menggunakan wujud maksim kerendahan hati. Hal ini dapat diketahui dari tuturan murid ketika mereka membicarakan teks yang disusun oleh Arij sangat bagus dan menarik. Percakapan dimulai dari seorang murid bertutur "Rek, teksnya Arij loh apik ya?". kemudian lawan tutur menanggapi "Iya mbk, Arij memang T-O-P-B-G-T. Alias pinter". Dan Kemudian lawan tutur (Arij) mematuhi maksim kerendahan hati dengan memaksimalkan rasa tidak hormat pada diri sendiri yaitu dengan tuturan "Walah, ndak kok. Lebih bagus punya kalian".

Kelima, maksim kecocokan adalah maksim yang mewajibkan agar setiap penutur dan lawan tutur memaksimalkan kesetujuan atau kecocokan di antara mereka; dan meminimalkan ketidaksetujuan di antara mereka. Jadi terdapat kecocokan antara pendapat penutur dan lawan tutur. Terdapat tuturan yang mengandung maksim kecocokan dalam percakapan interaksi guru dengan siswa di SMPN 2 krian, sebagai berikut:

Murid : Dea, paragraf satu teks

pohon jati masuk definisi umum ya?

Murid : Iya, definisi umum.

Karna menjelaskan

pengertian pohon jati.

(D1/Mkec/20Okt/02)

Kutipan di atas menunjukkan bahwa penutur dan lawan tutur menggunakan wujud maksim kecocokan. Percakapan diawali dari seorang murid yang bertanya kepada temannya dengan ujaran "Dea, paragraf satu teks pohon jati masuk definisi umum ya?". Kemudian pertanyaan tersebut dijawab oleh lawan tutur "Iya, definisi umum. Karna menjelaskan pengertian pohon jati". Lawan tutur setuju dengan pendapat atau pernyataan penutur bahwa pada paragraf satu teks pohon jati merupakan definisi umum dari teks laporan hasil observasi. Hal ini menunjukkan bahwa antara penutur dan lawan tutur saling setuju dengan hal yang sedang dibicarakan atau sedanag dibahas.

Keenam, maksim kesimpatian adalah maksim yang mengharuskan semua peserta pertuturan untuk memaksimalkan rasa simpati, dan meminimalkan rasa antipati kepada lawan tuturnya. Apabila lawan tutur mengalami musibah maka penutur wajib memberi ucapan belasungkawadan apabila lawan tutur mendapatkan rasa bahagia maka penutur harus memberi ucapan selamat. Terdapat tuturan yang mengandung maksim kesimpatian dalam percakapan interaksi guru dengan siswa di SMPN 2 krian, sebagai berikut:
Guru2 : Kemarin yang menang
lomba menulis siapa?
Murid : Debora bu.
Guru2 : Mana Debora? Selamat 


\section{ya Debora, jadi juara \\ dua lomba menulis. \\ Murid : Terima kasih bu. \\ (D1/Mkes/20Okt/01)}

Penggalan percakapan di atas merupakan percakapan antara guru dengan siswa yang menggunakan maksim kesimpatian. Seorang guru memberikan ucapan selamat atas kemenangan salah seorang muridnya dalam lomba menulis. Hal ini menunjukkan bahwa penutur (guru) mematuhi maksim kesimpatian dengan memberikan ucapan selamat atas apa yang dicapai oleh lawan tutur.

\section{PEMBAHASAN}

Interaksi antara siswa dengan guru di SMP Negeri 2 Krian sudah memenuhi prinsip kesantunan berbahasa berdasarkan pendapat Leech. Hal ini dikarenakan antara siswa dan guru saling menghormati dan saling membantu satu sama lain untuk memaksimalkan keuntungan orang lain. Hal ini sesuai dengan pendapat Kunjana (2003:45), penghormatan terhadap orang lain akan dapat terjadi hanya apabila orang dapat mengurangi kadar keuntungan bagi dirinya sendiri, dan memaksimalkan kadar keuntungan bagi pihak yang lainnya.

Maksim kebijaksanaan nampak terealisasikan pada penuturan siswa dengan guru di SMP Negeri 2 Krian. Hal ini seperti yang diungkapkan oleh Leech dalam Chaer (2010:56), pada maksim kebijaksanaan ini menggariskan bahwa setiap peserta pertuturan harus meminimalkan kerugian orang lain, atau memaksimalkan keuntungan bagi orang lain. Setiap peserta pertuturan meminimalkan kerugian orang lain, atau memaksimalkan keuntungan bagi orang lain. Salah satunya yaitu siswa menawarkan bantuan kepada guru dengan sedikit paksaan. Namun bukan paksaan yang kasar, siswa menawarkan bantuan dengan pertanyaan, misalnya dengan kata "kalau boleh". Namun maksim ini hanya terlihat dalam percakapan siswa dengan guru dan guru dengan siswa, tidak pernah terlihat pada penuturan siswa dengan siswa.

Hal ini dikarenakan siswa lebih menghormati gurunya dari pada teman sebayanya. Siswa kurang bijaksana dengan teman sebayanya dikarenakan mereka terlalu akrab dalam bergaul sehingga timbul rasa saling memberi bantuan atau meminjam tanpa adanya rasa sungkan. Seperti pendapat Rahardi (2003:47), kedekatan hubungan menyebabkan saling memberi dan meminjam, tanpa ada rasa sungkan.

Penggunaan maksim penerimaan juga terdapat pada tuturan interaksi siswa dengan guru. Pada tuturan siswa SMP Negeri 2 Krian terlihat bahwa siswa berusaha memaksimalkan keuntungan bagi orang lain dengan cara meminjamkan barang yang dibutuhkan oleh temannya. Siswa juga berusaha memaksimalkan keuntungan guru dengan menawarkan bantuan kepada guru.

Hal ini seperti yang diungkapkan oleh Rahardi (2003:48), dalam praktir bertutur yang sebenarnya, pihak yang satu harus senantiasa bermurah hati terhadap pihak lainnya. Menawarkan bantuan, memberikan sesuatu yang menjadi miliknya, meminjamkan barang-barangnya kiranya dapat dianggap pelaksanaan maksim kedermawanan (penerimaan) ini.

Sikap mau menerima seperti inilah yang menjadikan santun dan tidak ada perpecahan satu sama lain. Sikap tersebut dikarenakan karena adanya kedekatan 
hubungan antar penutur maupun lawan tutur. Seperti yang diungkapkan Rahardi (2003:47), kedekatan hubungan mereka berdua menyebabkan mereka saling memberi dan meminjamkan, tanpa ada rasa sungkan.

Penelitian Puspa Rinda (2011/2012) dengan Judul Analisis Kesantunan Berbahasa Siswa di Lingkungan Sekolah SMP Negeri 5 Binjai Tahun Pembelajaran 2011/2012, kesantunan berbahasa sangat dipengaruhi oleh jarak atau hubungan status antara penutur dengan mitra tutur. Semakin dekat jarak hubungan sosial kedua peserta tutur maka semakin tidak santun bahasa yang disampaikan. Sebaliknya semakin jauh jarak hubungan sosial maka semakin santunlah tuturan di antara peserta tutur.

Maksim kemurahan yang menuntut setiap peserta pertuturan untuk memaksimalkan rasa hormat kepada orang lain dan meminimalkan rasa tidak hormat kepada orang lain. Antara siswa dengan guru saling menghormati, misalnya siswa memuji guru dan sebaliknya guru memuji siswa. Menurut Nadar (2013:30) maksim diutarakan dengan tuturan ekspresif misalnya mengucapkan selamat dan memuji. Pada dialog interaksi di SMP Negeri 2 Krian guru sering memuji siswa, misanya memuji bahwa siswa itu pintar dan cerdas. Hal ini dilakukan guru untuk memotivasi siswa agar lebih giat belajar.

Maksim kerendahan hati yang menuntut setiap peserta pertuturan untuk memaksimalkan ketidakhormatan pada diri sendiri, dan meminimalkan rasa hormat pada orang lain. Hal ini sesuai pendapat Nadar (2013:30) maksim ini berpusat pada diri sendiri, menuntut untuk memaksimalkan rasa tidakhormat pada diri sendiri. Sering kali siswa ketika dipuji oleh guru maupun teman sebayanya, ia selalu merendahkan diri dengan cara mengelak. Misalnya guru memuji siswanya "kamu memang pintar ya nak", namun siswa mengelaknya "tidak bu, saya biasa saja lebih pintar Ibu". Hal ini dilakukan karena untuk menghormati lawan tutur (guru).

Maksim kecocokan mewajibkan agar setiap penutur dan lawan tutur memaksimalkan kesetujuan di antara mereka. Jadi terdapat kecocokan antara pendapat penutur dan lawan tutur. Maksim kecocokan sering muncul pada percakapan antara siswa dengan guru. Hal ini dikarenakan antara siswa dengan guru berada di situasi belajar mengajar di dalam kelas sehingga siswa memaksimalkan kecocokan dengan pendapat guru begitu juga sebaliknya guru memaksimalkan kecocokan dengan pendapat siswa karena keduanya berada di situasi dan kondisi yang sama. Rahardi berpendapat (2003:53), bahwa tindakan menentang, menyangga, atau melawan akan dianggap sebagai hal yang tidak sopan sama sekali, dan merupakan tindakan yang tidak terpuji sama sekali, makanya hal yang demikian itu harus dihindari.

Maksim kesimpatian yang mengharuskan semua peserta pertuturan untuk memaksimalkan rasa simpati, dan meminimalkan rasa antipati kepada lawan tuturnya. Dalam temuan data guru memberi selamat kepada murid, misalnya memberi selamat karena siswa berhasil menjadi juara dalam lomba.

Dari keenam maksim yang ada, maksim yang lebih dominan pada interaksi siswa dengan guru yaitu maksim kecocokan. Maksim kecocokan lebih dominan karena antara siswa dengan guru berada di situasi dan kondisi yang sama yakni di dalam ruang kelas ketika kegiatan belajar mengajar berlangsung. Jadi intensitas kecocokan pendapat semakin banyak pula. Antara siswa dan guru sepemikiran 
karena keduanya sedang berada di situasi yang sama dan sedang membicarakan permasalahan yang sama.

Rahardi berpendapat (2003:53), bahwa tindakan menentang, menyangga, atau melawan akan dianggap sebagai hal yang tidak sopan sama sekali, dan merupakan tindakan yang tidak terpuji sama sekali, makanya hal yang demikian itu harus dihindari. Dengan memaksimalkan kecocokan atau kesetujuan dengan pendapat lawan tutur, maka antara penutur dan lawan tutur akan dapat dikatakan sebagai pribadi yang santun. Begitu juga yang terjadi di SMP Negeri 2 Krian, antara siswa dengan guru sama-sama saling memaksimalkan kecocokan antara keduanya dengan berusaha menyetujui pendapat satu sama lain. Hal ini juga dipengaruhi oleh faktor umur dan menghormati orang yang lebih tua. Apabila sedang berbicara dengan orang yang umurnya lebih tua maka akan beusaha memaksimalkan rasa hormat dengan cara memaksimalkan pula rasa kesetujuan dengan apa yang diutarakan.

Maksim kesimpatian sangat sedikit sekali terlihat di tuturan siswa dengan guru maupun siswa dengan siswa. Hanya terlihat guru yang simpati dengan murid. Guru memaksimalkan rasa simpati kepada murid dengan ucapan selamat kepada siswa yang memenangkan lomba. Hal ini dilakukan guru untuk memotivasi siswa agar lebih produktif lagi dalam berkarya dan lebih giat belajar. Namun rasa simpati siswa dengan sebayanya amat sangat kurang. Terbukti jarang sekali siswa yang mengucapkan rasa simpati kepada temannya, mereka hanya memuji temannya. Karena diusia mereka yang saat ini (kurang lebih 12 tahunan) mereka memiliki rasa bersaing yang tinggi. Apabila ada teman mereka yang memenangi lomba menulis misalnya, mereka masih mempunyai rasa iri karena adanya rasa bersaing yang kuat. Hal inilah yang membuat kurangnya rasa simpati pada siswa SMP.

\section{SIMPULAN}

Berdasarkan temuan penelitian, maka dapat ditarik simpulan yakni wujud penerapan prinsip kesantunan berbahasa dalam interaksi percakapan antara siswa dengan guru di SMP Negeri 2 Krian. Dalam tuturan interaksi siswa dengan guru terdapat maksim kesantunan berbahasa. Maksim tersebut adalah maksim (1) Maksim kebijaksanaan terdapat 4 ujaran; (2) Maksim penerimaan terdapat 4 ujaran; (3) Maksim kemurahan terdapat 18 ujaran; (4) Maksim kerendahan hati terdapat 10 ujaran; (5) Maksim kecocokan terdapat 87 ujaran; dan (6) Maksim kesimpatian terdapat 2 ujaran.

Dari keenam maksim yang ada, maksim yang lebih dominan pada interaksi siswa dengan guru yaitu maksim kecocokan. Maksim kecocokan lebih dominan karena antara siswa dengan guru berada di situasi dan kondisi yang sama yakni di dalam ruang kelas ketika kegiatan belajar mengajar berlangsung.

Maksim kesimpatian sangat sedikit sekali terlihat di tuturan siswa dengan guru maupun siswa dengan siswa. Hanya terlihat guru yang simpati dengan murid. Hal ini dilakukan guru untuk memotivasi siswa agar lebih produktif lagi dalam berkarya dan lebih giat belajar.

Dengan demikian dapat dinyatakan bahwa interaksi siswa dengan guru di SMP Negeri 2 krian sudah mematuhi prinsip kesantunan berbahasa. Sehingga interaksi antara siswa dengan guru dapat dikategorikan santun dalam berbahasa. 


\section{SARAN}

Berdasarkan hasil penelitian dapat dikemukakan bebrapa saran yang dapat menjadi bahan masukan yang bermanfaat antara lain.

Bagi peneliti yang akan datang, penelitian ini dapat diperdalam dengan penelitian selanjutnya, dengan aspek alin yang tidak diteliti dalam penellitian ini. Serta dapat dijadikan reverensi pada penelitian selanjutnya.

Bagi Sekolah penelitian ini dapat memberikan masukan sebagai bahan pembelajaran prinsip kesantunan bahasa dalam tuturan kepada pihak SMP Negeri 2 Krian. Hasil penelitian ini bermanfaat untuk memecahkan masalah kesantunan bahasa yang dihadapi sekolah-sekolah pada umumnya. Sehingga siswa dapat bertutur kata dengan santun ketika berkomunikasi baik di lingkungan sekolah maupun di masyarakat.

\section{DAFTAR PUSTAKA}

Chaer, Abdul. 2010. Kesantunan Berbahasa. Jakarta: Rineka Cipta.

Nadar, F.X. 2013. Pragmatik dan penelitian Pragmatik. Yogyakarta: Graha Ilmu.

Keraf, Goryf. 2004. Komposisi. Flores: Nusa Indah.

Rahardi, Kunjana. 2003. Perkenalan dengan Ilmu Bahasa Pragmatik. Malang: Penerbit Dioma.

Sudaryanto. 1988. Metode Linguistik Bagian Kedua Mrtode dan Aneka Teknik Pengumpulan Data. Yogyakarta: Gadja Mada University Press.

Tarigan, Henry Guntur. 2008. Berbicara Sebagai Suatu Keterampilan Berbahasa. Bandung: Angkasa Bandung.

Sasindo. 2012. Jurnal. http:// jurnal. unimed. ac. Id/ 2012/ index.php/ sasindo/ article/ view/ 421. Diunduh Hari: Minggu, 03 Agustus 2014-08-03. Pukul: 19.15 WIB 